\title{
EoW Criteria for Waste-Derived Aggregates
}

\author{
Ole Hjelmar • Hans A. van der Sloot • \\ Rob N. J. Comans • Margareta Wahlström
}

Received: 27 November 2012/ Accepted: 11 June 2013/Published online: 30 July 2013

(c) The Author(s) 2013. This article is published with open access at Springerlink.com

\begin{abstract}
Waste-derived aggregates are being considered as possible candidates for development of End-of-Waste (EoW) criteria at European Union (EU) level in accordance with Article 6 (1) of the EU Waste Framework Directive (2008/98/EC) as a means of increasing the recovery of resources from waste. If a waste-derived aggregate achieves EoW status, it will become a (construction) product and hence be regulated by the Construction Products Regulation (CPR) which means that in most EU Member States there will be no applicable environmental protection regulation. It is therefore important that the criteria a waste-derived aggregate must fulfil to achieve and maintain EoW status ensure sufficient protection of the environment and human health. It is shown that EoW criteria that do not include restrictions on the conditions of the use of waste-derived aggregates for specific construction purposes will result in
\end{abstract}

O. Hjelmar $(\bowtie)$

DHI, Agern Allé 5, 2970 Hørsholm, Denmark

e-mail: oh@dhigroup.com

H. A. van der Sloot

Hans van der Sloot Consultancy, Dorpstraat 216, 1721 BV

Langedijk, The Netherlands

e-mail: hans@vanderslootconsultancy.nl

R. N. J. Comans

ECN, P.O. Box 1, 1755ZG Petten, The Netherlands

e-mail: rob.comans@wur.nl

Present Address:

R. N. J. Comans

Department of Soil Quality, Wageningen University, P.O. Box

47, 6700 AA Wageningen, The Netherlands

M. Wahlström

VTT, Biologinkuja 7, FI 02150, Espoo, Finland

e-mail: margareta.wahlstrom@vtt.fi leaching limit values that are so stringent that very few, if any, waste-derived aggregates can meet them. It is therefore proposed to impose restrictions and conditions on the use as part of possible future EoW criteria for waste-derived aggregates, and a step-wise methodology for development of more realistic leaching limit values for EoW is outlined. The methodology incorporates the mitigating effects of various measures that reduce the potential environmental impact of construction applications with waste-derived aggregates. Recommendations are also made of the practical testing and documentation procedures for aggregates with EoW status within the framework of the CPR.

Keywords End-of-Waste - Waste-derived aggregates · Risk-based leaching criteria $\cdot$ Construction Products Regulation · Water protection

\section{Introduction}

The 2008 revision of the European Union (EU) Waste Framework Directive (WFD) [1] introduces the option of setting so-called End-of-Waste (EoW) criteria under which specified waste fractions shall cease to be waste. If these criteria are fulfilled, the material will no longer be classified as a waste but rather become a product subject to free trade and use (albeit for specific purposes). According to Article 6 (1) of the WFD, a waste material may cease to be waste as defined in the WFD when it has undergone a recovery, ${ }^{1}$

\footnotetext{
${ }^{1}$ In the WFD recovery is defined as any operation the principal result of which is waste serving a useful purpose by replacing other materials which would otherwise have been used to fulfil a particular function, or waste being prepared to fulfil that function, in the plant or in the wider economy. The WFD provides a list of recovery operations.
} 
including recycling, ${ }^{2}$ operation and complies with specific criteria to be developed in accordance with the following conditions:

(a) the material is commonly used for specific purposes;

(b) a market or demand exists for such a material;

(c) the material fulfils the technical requirements for the specific purposes and meets the existing legislation and standards applicable to products;

(d) the use of the material will not lead to overall adverse environmental or human health impacts.

The criteria shall include limit values for pollutants where necessary and shall take into account any possible environmental effects of the material.

The Joint Research Centre (JRC), Institute for Prospective Technology Studies (IPTS) in Seville, Spain, which is part of the EU Commission, has been charged with the responsibility of further developing the concept of EoW. On request from the EU Commission's DirectorateGeneral for the Environment, the JRC-IPTS has carried out two studies where the first was aimed at defining the concept of EoW and developing a general classification methodology (Delgado et al. [2]) and the second was aimed at identifying waste streams suitable for non-waste classification (IPTS [3]). The latter study has identified three different waste streams:

1. Streams that are in line with the basic principles of EoW and suited for further EoW criteria assessment;

2. Streams that may be in line with the principles;

3. Streams that are not considered appropriate for EoW classification.

The first category of waste streams has been further divided into two sub-categories, namely:

(1.1) Streams used as feedstock in industrial processes, a pathway that controls the risks of health and environmental damage. These streams include metal scrap of iron and steel, aluminium, copper, plastics, paper, textiles, glass, metal scrap of zinc, lead and tin, other metals;

(1.2) Streams used in applications that imply direct exposure to the environment. In these cases, the EoW criteria to be developed in the further assessment shall include where necessary limit values for leaching pollutants, taking into account any possible adverse environmental and health

\footnotetext{
${ }^{2}$ In the WFD recycling is defined as any recovery operation by which waste materials are reprocessed into products, materials or substances whether for the original or other purposes. It includes the reprocessing of organic material but does not include energy recovery and the reprocessing into materials that are to be used as fuels or for backfilling operations.
}

effects. The streams in this subcategory are: Construction and demolition (C\&D) waste aggregates, ashes and slag, bio-waste materials stabilised for recycling (e.g., compost).

End-of-Waste legislation has recently (in 2011) been implemented at EU level for scrap steel and aluminium (type 1.1 streams) in the form of a Regulation [4], and efforts are underway to develop European EoW criteria for copper and copper alloy scrap (1.1), glass cullets (1.1), paper (1.1), compost (1.2) and plastics (1.1). In addition, various types of aggregates (streams of granular waste materials of type 1.2) are under consideration as possible candidates for development of EoW criteria EU level.

The WFD allows individual Member States to develop national EoW criteria for wastes that fulfil the conditions (a)-(d) above and for which EU criteria have not (yet) been developed. As of 2012, only the UK has set up specific procedures and started developing national EoW criteria for specific types of waste materials, including some aggregates [5].

Waste-derived aggregates, including for example C\&D waste and various slags and ashes are widely used for construction purposes in several EU Member States, subject to national waste regulation conditions and criteria (Böhmer et al. [6]). Achievement of EoW status at EU level for one or more streams of waste aggregates could therefore not only improve the possibilities of recycling those aggregates as valuable resources as intended but also potentially give rise to unacceptable environmental impacts, depending on the criteria and conditions specified.

Whereas there is little doubt that several streams of waste-derived aggregates fulfil the requirements listed under the above indent (a) - the material is commonly used for specific purposes-and indent (c) - the material fulfils the technical requirements for the specific purposes and meets existing legislation and applicable standards-there has been some discussion as to whether several recycled waste aggregates actually meets the condition listed under indent (b): A market or demand must exist for the material. It is not clear from the text in the WFD whether this means that the material to be used with EoW status should have a real positive monetary value, or if it is sufficient that the beneficial use of the material as a product off-sets the cost of alternative management such as landfilling that would have had to be paid if the material remained a waste and was not recycled. The situation today in several EU Member States is that part of the incentive for beneficial use of waste aggregates is the saved cost of landfilling, including the landfill tax in some countries. So far (2012), no clarification of this issue has been provided by the EU Commission.

However, the main potential controversies related to the possible application of the EoW option to waste aggregates 
appear to be associated with the fulfilment of indent (d): the use of the material must not lead to overall adverse environmental or human health impacts, and the need for appropriate test methods and limit values, particularly on leaching. In this paper we discuss these issues based on a broad experience in relevant fields and what we believe is a logical interpretation of the environmental protection intentions of the involved legislation. It has been our intention to take a scientific approach to the issues without losing touch with practical matters.

First the regulatory implications and consequences of EoW for aggregates are discussed. Then, after a brief discussion of risk and impact assessment, the different approaches of "free use" and "conditional use" under EoW and the consequences for the leaching limit values are discussed, and various conditions of use that can lead to higher (and more attainable) leaching limit values are presented. Finally, a methodology is outlined and proposed for development of EoW criteria and use conditions for aggregates that can provide adequate protection against potential environmental impacts caused by leaching and migration of potentially harmful substances from applications of such aggregates. A proposal for appropriate test methods and documentation requirements under the CPR is also provided.

\section{Regulatory Consequences of EoW for Aggregates}

When classified as a waste, environmental and health protection aspects of the use of waste aggregates for construction purposes within the EU are regulated by national (and EU) waste legislation. Technical or functional requirements for the use of waste aggregates for construction purposes are regulated under the Construction Products Regulation (CPR, [6]) which on 1 July 2013 fully replaced the Construction Products Directive (CPD, [7]) by means of harmonised European Product Standards and the $\mathrm{CE}$ marking of construction products. The harmonised European standards for aggregates distinguish between primary, secondary and recycled aggregates and thus cover both waste materials and products used in construction. Generally, all three types must fulfil the same technical requirements in order to be used as aggregates in the European common market.

If a waste aggregate obtains EoW status and ceases to be waste in accordance with Article 6 (1) of the WFD and any additional criteria that may be developed, it becomes a product. In that case it will no longer be regulated by waste legislation, and the environmental and health protection measures embedded in the waste legislation will no longer apply. Instead the use of the material will be regulated entirely by legislation on products. When used for construction purposes the waste-derived aggregate with EoW status will still be covered by the CPD/CPR and possibly also by REACH [8] (no consolidated evaluation from the Commission is available at this time although some guidance may be found in a publication from the European Chemicals Agency, ECHA [9]). In addition, other EU and national legislation may have a direct or indirect influence on the use or conditions of use of wastederived aggregates with EoW status.

The marketing and use of a waste-derived aggregate, which obtains EoW status and becomes a construction product, will as mentioned above still be regulated by the $\mathrm{CPD} / \mathrm{CPR}$ as far as the functional criteria and CE marking are concerned. The CPD was replaced by the Construction Products Regulation (CPR) on 9 March 2011 but with a transition period that allows CE marking and marketing of construction products in accordance with the CPD until 1 July 2013. Currently the European Standardisation organisation CEN is working under mandates from the EU Commission to implement Essential Requirement no. $3^{3}$ (ER3) in the CPD addressing health, hygiene and the environment into the various product standards describing the conditions for $\mathrm{CE}$ marking. The product standards will describe which (harmonised) test standards must be used at EU level to measure the potential release to soil, groundwater and surface water. In contrast to the CPD (which only considers the service life of a construction product), the CPR addresses the entire lifecycle of the construction products, but most likely it will take several years to implement this into the product standards. The criteria to be met by the test results to allow marketing and various uses of the products are, however, not set at EU levelthey depend on national regulation in each EU Member State (and associated countries). If such criteria existed, they would presumably provide the necessary protection of soil, groundwater and surface water regardless of the origin of the construction products.

At present however, very few EU Member States have actually set environmental protection criteria for the use of construction products. Only The Netherlands have legislation in place that regulates the release to soil, surface water and groundwater from construction products used in various applications. The Dutch Soil Quality Decree (SQD [10]) specifies environmental quality criteria for the application of stony materials (including excavated soil) in construction, and does not distinguish between products

\footnotetext{
${ }^{3}$ ER3 is one of six so-called Essential Requirements in the CPD (one of seven in the CPR where they are referred to as Basic Requirements) that constitute the basis for the technical specifications in the harmonised product standards. The CPD was adopted in 1988, but the implementation of ER 3 Hygiene, health and the environment was not initiated until 2005 (as the last of the six ERs) and the work is still ongoing (2012).
} 
and waste materials. This means that in The Netherlands, the level of environmental protection will not change if a waste aggregate obtains EoW status and shifts from waste legislation to product legislation. In most other EU Member States the situation is quite different: Whereas several Member States have found it necessary to require testing and set limit values for leaching of potentially harmful substances from recycled waste aggregates used for various construction purposes [11], very few if any of these Member States have similar regulation for construction products (which could be the same materials if they are awarded EoW status) that are not covered by waste legislation. The effect is that in those Member States a waste material with EoW status at EU level is no longer subject to any environmental quality criteria or specific use conditions aimed at environmental protection, except for those laid down in the requirements for obtaining the EoW status itself. This must be taken into account if and when criteria and conditions for obtaining and maintaining EoW status for waste-derived aggregates are developed.

It seems possible that the option to develop national EoW criteria for certain waste types could lead to problems if an aggregate gains EoW status and becomes a product in one EU Member State and is exported to other Member States where it is still considered a waste. This issue has been dealt with in the UK where EoW criteria have been developed e.g., for coal fly ash in bound applications. In the Quality Protocol for Pulverised Fuel Ash [12] it is stated that if the material is exported to a country where it is considered a waste, the shipment will be subject to the controls set out in the EU Waste Shipment Regulation [13].

\section{Development of EoW Limit Values for Leaching}

\section{Conceptual Risk/Impact Assessment Model}

The risks or impacts posed by aggregates (natural, secondary or recycled) to the environment or human health can be conceptually described as a chain of events, see Fig. 1. This well-established and commonly used chain consists of the identified potential contamination source(s) and receptor(s) as well as the potential migration pathways between them. A risk or impact only arises if the chain remains unbroken and there is a negative effect at the receptor. The conceptualisation of risk/impact as a chain can be seen as a descriptive tool and will be used as such in this context, but the chain of events can be much more formalised with event-oriented risk assessment models. From a systematic perspective it is generally useful to consider each part of the chain separately as the basis for impact assessment scenarios and the associated calculation models.

In this context, the main emphasis will be on evaluation of relevant combinations of sources, pathways and receptors associated with the release of substances from aggregate applications by leaching, direct contact with or transport through soil and aquifers or surface water bodies to points of evaluation or compliance in soil, surface water or groundwater (primary receptor). The actual or final receptor will be the humans or the ecosystem that by use of or contact with the primary receptor are affected by the impact. The relevant quality criteria to be set and complied with at the primary receptor are reflected by and should be based on existing EU or national legislation on groundwater, surface water and soil quality.

Exposure routes such as inhalation, ingestion, direct contact and occupational exposure will not be addressed in this context. They can largely be based on existing national legislation on maximum content of (dangerous) substances in materials (e.g., waste aggregates and soil) that can be used without restrictions and which sufficiently reflect and protect against the risks associated with these exposure routes.

The conceptual model described above will be relevant in relation to any use of secondary or recycled aggregates regulated under waste legislation as well as for the use of aggregates in general regulated by environmental and health protection measures under construction product legislation or under the WFD as part of the re-classification procedure. It will therefore also be applicable to the assessment of the potential risks associated with the use of waste aggregates that have obtained EoW status. It should be noted that the methodology used to set EoW criteria for waste derived aggregates in relation to environmental protection in principle is independent of the aggregate in question-except for the fact that the types of substances that may be critical in terms of impact may and will vary from one type of aggregate to another.

In relation to the potential impact from leaching, the receptor could simply be described in terms of a point of compliance (POC) at the end of the pathway (in soil,

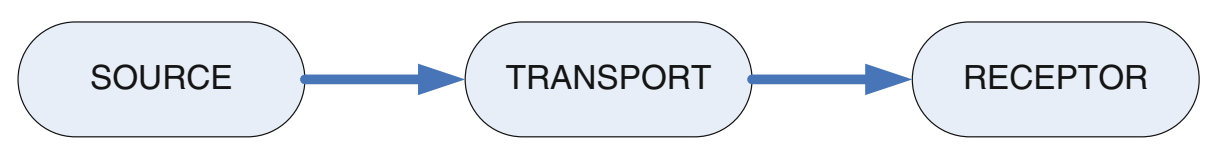

Fig. 1 The concept of risk/impact illustrated as a chain of events. For a risk or impact to occur, the chain must remain unbroken, and an undesired effect must occur at the receptor 
groundwater or surface water) where some (primary) water or soil quality criteria must be fulfilled [14]. Typically such criteria could be the maximum acceptable concentrations in the groundwater or surface water at the POC. The primary quality criteria are totally independent of the nature of the source, and in principle also of the pathway.

\section{EoW Use Without or With Conditions/Restrictions}

Article 6 (1) in the WFD refers to "specific" purposes in indent (a), and this is repeated in indent (c) which addresses the fulfilment of the technical requirements for the "specific" purposes. It leads to the question of whether or not the use of a waste-derived aggregate with EoW status should be restricted to certain "specific" purposes under certain specified conditions. Since the EU Commission has not (yet) provided a consolidated opinion on this, it seems useful to initially consider both situations, i.e., on the one hand the situation where a waste aggregate with EoW status can be used and traded freely without any restrictions, and on the other hand the situation where the same product can be used only for specific purposes under specified conditions. The two situations will lead to very different assessments of the potential environmental impacts and, as a consequence, to very different environmental protection criteria and leaching limit values for achievement of EoW status.

This section outlines some potential use scenarios for aggregates, including a scenario illustrating a "worst case" of free use without restrictions. The next section shows the potential consequences of free use in terms of very stringent leaching limit values, and the following three sections show how conditions can be imposed on the use and how they can be incorporated into a methodology for development of (less stringent) leaching criteria for EoW for waste-derived aggregates, and provide an option for testing and documentation with respect to the CPR.

It is the opinion of the authors that if EoW criteria are to be developed for waste-derived aggregates at EU level, to be in accordance with existing environmental and human health protection legislation without resulting in forbiddingly low criteria, they should ensure:

1. A high degree of certainty that aggregates used under the EoW status actually fulfil the EoW criteria to be developed. This implies sufficient proof (e.g., in the form of a dossier) of absolute compliance with the criteria up front and effective subsequent quality control measures.

2. That the generally acknowledged source-pathwayreceptor scenarios upon which the development of EoW environmental and health protection criteria should be based reflect the presence or absence of any restrictions or conditions imposed on the use of waste-derived aggregates with EoW status.

3. That the environmental protection measures established take into account that most EU Member States have no legislation that regulates the potential environmental impact of construction products.

4. That the source-pathway-receptor scenarios upon which the EoW environmental and health protection criteria should be based address not only the service life situation (i.e., the period during which the aggregate serves an intended and useful purpose) but rather the entire lifecycle, and in particular the end-oflife (EoL) situation (where the aggregate, if left unattended, may disintegrate and become exposed over a long time period to ambient conditions that may favour the release of potentially polluting substances). This implies the inclusion of source term scenario(s) that reflect maximum and long term exposure conditions and includes the effects of potential chemical changes (e.g., carbonation of alkaline materials).

If no restrictions or conditions are placed on the use of waste-derived aggregates with EoW status, then in the assessment of the potential impact and/or the development of leaching limit values the source term must account for the "worst case" release that may potentially take place. This would include testing of size reduced material both under initial conditions (first pore water composition) and under long term exposure conditions to determine the potential maximum release of substances.

An aggregate product which can be used and traded freely without restrictions could in principle end up anywhere, and it could theoretically be used as a filling material in a small, sensitive lake. This is illustrated in Fig. 2.

If, on the other hand, some restrictions and control measures were placed on the application of aggregates with EoW status, the scenario conditions used to assess the leaching results could be less severe without compromising the safety of the environment and human health. This is illustrated in Fig. 3.

The heap of aggregate material placed in the lake as shown in Fig. 2 (or in direct contact with the groundwater) should perhaps be characterised as a mismanagement scenario rather than a use scenario, but it does represent a risk that should be taken into account, if no restrictions are placed on the use of waste-based aggregates with EoW status which are placed on the market.

Figure 3 shows some aspects of normal use scenarios for both aggregate products and waste aggregates where top covers may reduce the rate of infiltration, and where migrating contaminating substances may be attenuated in the unsaturated and saturated zones before reaching the 
Fig. 2 Scenario describing a worst case environmental impact for waste derived aggregates with EoW status and without any restrictions on the use. In this case a large amount of aggregate is in direct contact with a sensitive lake and may release substances directly into the water
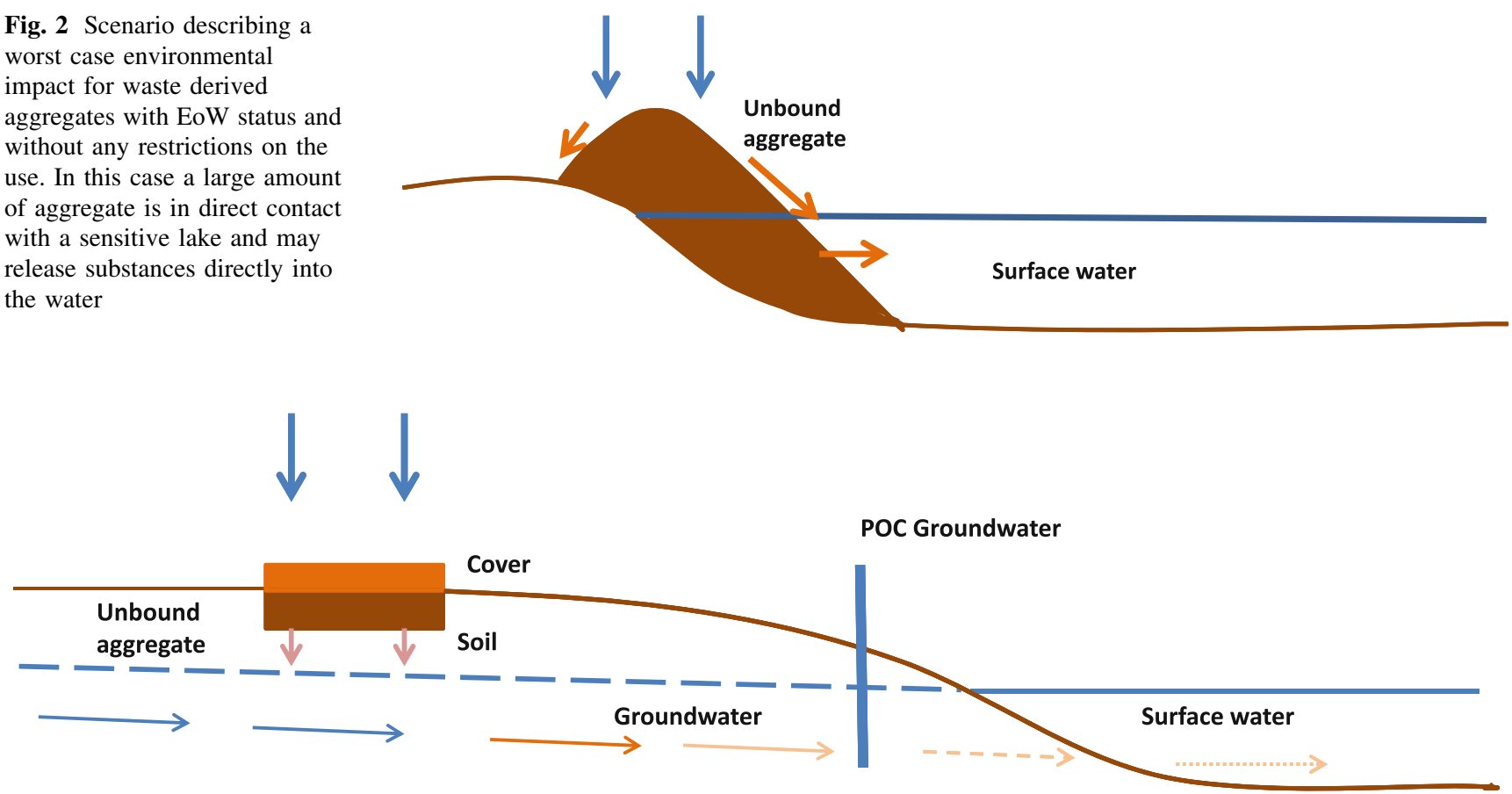

Fig. 3 Example of an environmental impact scenario which takes into account various restrictions and use conditions imposed on the use of waste-derived aggregates (here) with EoW status.

POC which may be downstream groundwater or surface water. Some typical potential uses of waste-derived aggregates with (or without) EoW status, are unbound use in base and sub-base layers under roads, parking lots, highway ramps, house foundations, in noise reduction barriers, and in hydraulically bound applications (e.g., concrete).

The entire life-cycle of the material in the application should be taken into account, and the source term scenario must reflect this in terms of maximum potential release of substances. Based on experimental evidence it seems safe to assume that the leaching of most substances from an intact bound material will be less extensive than the leaching of the same substance from the same material in a crushed or crumbled state. Since a bound material (and a coarse unbound material) may eventually end up in a crumbled state with small particle sizes in the EoL stage, aggregates used in bound applications should be tested in that crumbled/crushed state, and the source term scenario(s) for these materials should be based on this and include the potential effects of ageing, carbonation and changes in $\mathrm{pH}$ and redox potential. This means that, when the EoL stage is considered, the same physical source term scenarios can be used to describe the release of substances from both bound and unbound conditions.

For a given (chosen) source term scenario, the source term should describe the release of relevant substances as a function of time over the relevant timeframe in terms of
POC $=$ point of compliance. The cover limits the amount of water percolating through the aggregate and the released substances are attenuated by the soil and the aquifer

quantity and quality of the leachate, i.e., the flux of released substances as a function of time. If conditions are imposed for the use of the aggregate with EoW status, the effect of these conditions should be reflected in the scenario and the source term. The source term description for a given aggregate will generally be based a combination of leaching test results, assumed scenario conditions and modelling. The pathway/transport scenarios will form the basis for modelling of the transport of substances from the application to the primary receptor using the output from the source term as input to the transport model(s).

\section{EoW Criteria Without Restrictions or Conditions on the Use}

To illustrate the possible consequences in terms of very stringent leaching limit values of developing EoW criteria for waste-derived aggregates without placing restrictions or conditions on their use as products, leaching limit values are calculated using the environmental impact scenario discussed above and shown in Fig. 2. In many cases the concentrations of the substances of interest that occur in the initial pore water upon water saturation or percolation of an application with a granular or size reduced aggregate will represent the highest and hence the critical values to be used in the source term. Since there are no restrictions imposed, it should be assumed that the application (or heap) could be relatively high (5-10 $\mathrm{m}$ or more) and that 
the rate of infiltration of precipitation into the application (or heap) and hence the rate of production of leachate could be substantial (e.g., 300-350 mm/year or more under Northern European conditions). Although the highest concentrations for most substances are seen in the initial pore water, (i.e., at low liquid to solid ratios, $\mathrm{L} / \mathrm{S}^{4}$ ), some substances, particularly those that are solubility controlled, may show increasing concentrations when the L/S ratio increases over a certain range, e.g., due to removal of other substances or due to changes (decreases) in $\mathrm{pH}$ as a result of carbonation. Many relevant waste-derived aggregates, including crushed concrete, will have a relatively high starting pH (typically 10-12.5) that may be reduced over time to more neutral values by natural carbonation resulting from exposure to atmospheric carbon dioxide. The testing should reflect the effects of the possible change of $\mathrm{pH}$ over time or due to removal of solubility controlling substances.

In this case of unrestricted use the pathway is simple: Due to the lack of restrictions, it is necessary to assume that the material can be placed in direct contact with the receptor, which can be groundwater or surface water, so there is no pathway along which attenuation of released substances can take place. The source (initial pore water) is discharged directly into the receptor.

The receptor will be groundwater or surface water. It is proposed to use either national values or European values as the primary water quality criteria (WQC). In this calculation, the lowest national WQC for groundwater or surface water should be used. Some of the chosen WQC which are shown in Table 1 (e.g., chloride and sulphate) are extremely low compared to ecotoxicological quality levels but since they have been used officially for fresh surface water receptors in calculations of Swedish guidance limit values for free use of waste [15], they are taken along for consistency. For the sake of this example, the limit values have been calculated only for the primary WQC corresponding to the substances for which the EU waste acceptance criteria (WAC) for inert waste landfills were set [16], using the very low Scandinavian WQC. If EoW criteria for aggregates are developed (with or without restrictions on the use), it will probably be necessary to consider a broader range of substances for which primary

\footnotetext{
${ }^{4} \mathrm{~L} / \mathrm{S}$ (the liquid to solid ratio) describes the ratio between the amount of liquid (water) measured in litres and the amount of solid (e.g., aggregate) measured in $\mathrm{kg}$ dry mass, which is brought into contact with each other in a leaching test or in a leaching scenario. For batch or percolation leaching tests the results are often described in terms of accumulated release (e.g., in $\mathrm{mg} / \mathrm{kg}$ ) or eluate concentration (e.g., in $\mathrm{mg} / \mathrm{l}$ ) of a substance as a function of L/S. Expressing accumulated release as a function of L/S allows direct comparison between results from different leaching tests and sometimes also comparisons between field observations and results of leaching tests. For specific use scenarios the L/S scale may be re-calculated to a time scale.
}

WQC should be selected and limit values calculated, also taking into account the requirements of the Water Framework Directive [17] and its implementation. Since the aggregate heap in this scenario in principle may be large and the sensitive lake small, the rather stringent acceptance criterion used here for the sake of illustration is simply that the initial pore water concentration in the aggregate material must not exceed the chosen WQC. No dilution is assumed.

A pore volume of $\sim 0.3$ of a water-saturated aggregate with a dry bulk density of about $1.5 \mathrm{t} / \mathrm{m}^{3}$ will correspond to an $\mathrm{L} / \mathrm{S}$ value of $\sim 0.2 \mathrm{l} / \mathrm{kg}$. If it is assumed that an initial pore water concentration corresponding to the WQC is the limit value for a given substance, the initial pore water concentration of that substance in a given, saturated aggregate can be "translated" to estimates of the accumulated release of the substance at other L/S values (e.g., 2 or $10 \mathrm{l} / \mathrm{kg}$ ) assuming a simplified description of the system as a continuously stirred tank reactor (CSTR) resulting in a simple exponential decrease of the concentration as a function of L/S (see e.g., Hjelmar et al. [18] and van der Sloot et al. [19]), using a kinetic substance-specific constant, the so-called kappa ( $\kappa)$ value to describe the release (tables with "generic" kappa values may e.g., be found in [20] or can be generated for for a specific material based on percolation data). The calculated limit values can then be compared to results of the percolation leaching test CEN/ TS 14405 or the batch leaching tests EN 12457-1, -2 or -3 at $\mathrm{L} / \mathrm{S}=2$ and/or $10 \mathrm{l} / \mathrm{kg}$ for compliance assessment. At $\mathrm{L} / \mathrm{S}=10 \mathrm{l} / \mathrm{kg}$ the limit values can also be compared to the results of the $\mathrm{pH}$ dependence tests CEN/TS 14997 and CEN/TS 14429 at L/S $=10$ l/kg carried out at relevant $\mathrm{pH}$ values. Table 1 shows leaching limit values for aggregates calculated in this way using very stringent groundwater or (fresh) surface WQC from the Nordic countries as the primary WQC and assuming this value in the porewater at $\mathrm{L} / \mathrm{S}=0.2 \mathrm{1} / \mathrm{kg}$. The CSTR model has been used in setting leaching criteria for landfilling at EU level [14] as well as leaching criteria for use of construction products in some EU member states (see e.g., [10]).

It is evident from Table 1 that the leaching limit values calculated for free use of waste-derived aggregates without any conditions on the use are very low and restrictive, and for many substances orders of magnitude lower than the EU WAC for inert waste landfills which are also shown. Very few, if any, waste-derived aggregates will be able to comply with these criteria.

\section{Conditions that Can Modify EoW Leaching Limit Values}

Some of the conditions that could be imposed on the use of a given waste-derived aggregate with EoW status are listed 
Table 1 The calculated leaching limit values at $\mathrm{L} / \mathrm{S}=0.21 / \mathrm{kg}, 2 \mathrm{l} /$ $\mathrm{kg}$ and $101 / \mathrm{kg}$ as (part of) EoW criteria without restrictions and control of the use. The table also shows the water quality criteria and kappa values used in the calculation of the limit values as well as the $\mathrm{EU} \mathrm{WAC}$ at $\mathrm{L} / \mathrm{S}=10 \mathrm{l} / \mathrm{kg}$ for inert waste landfills

\begin{tabular}{|c|c|c|c|c|c|c|}
\hline \multirow[t]{2}{*}{ Substance } & \multirow{2}{*}{$\begin{array}{l}\text { WQC } \\
\mu \mathrm{g} / 1\end{array}$} & \multirow{2}{*}{$\begin{array}{l}\text { Kappa }(\kappa) \\
\mathrm{kg} / 1\end{array}$} & \multicolumn{3}{|c|}{ Calculated limit values } & \multirow{2}{*}{$\begin{array}{l}\text { EU Inert landfill WAC } \\
\mathrm{L} / \mathrm{S}=101 / \mathrm{kg} \\
\mu \mathrm{g} / \mathrm{kg}\end{array}$} \\
\hline & & & $\begin{array}{l}\mathrm{L} / \mathrm{S}=0.21 / \mathrm{kg} \\
\mu \mathrm{g} / \mathrm{kg}\end{array}$ & $\begin{array}{l}\mathrm{L} / \mathrm{S}=21 / \mathrm{kg} \\
\mu \mathrm{g} / \mathrm{kg}\end{array}$ & $\begin{array}{l}\mathrm{L} / \mathrm{S}=101 / \mathrm{kg} \\
\mu \mathrm{g} / \mathrm{kg}\end{array}$ & \\
\hline Chloride & 15,000 & 0.57 & 3,000 & 19,000 & 28,000 & 800,000 \\
\hline Fluoride & 1,500 & 0.22 & 300 & 2,500 & 6,200 & 10,000 \\
\hline Sulphate & 30,000 & 0.33 & 6,000 & 45,000 & 90,000 & $1,000,000$ \\
\hline As & 0.3 & 0.03 & 0.060 & 0.58 & 2.6 & 500 \\
\hline $\mathrm{Ba}$ & 9.3 & 0.15 & 1.9 & 16 & 49 & 20,000 \\
\hline $\mathrm{Cd}$ & 0.02 & 0.5 & 0.004 & 0.027 & 0.042 & 40 \\
\hline $\mathrm{Cr}$ & 0.3 & 0.18 & 0.06 & 0.51 & 1.4 & 500 \\
\hline $\mathrm{Cu}$ & 12 & 0.28 & 2.4 & 19 & 41 & 2,000 \\
\hline $\mathrm{Hg}$ & 0.005 & 0.05 & 0.001 & 0.01 & 0.04 & 10 \\
\hline Mo & 20 & 0.35 & 4 & 30 & 57 & 500 \\
\hline $\mathrm{Ni}$ & 1 & 0.29 & 0.2 & 1.6 & 3.4 & 400 \\
\hline $\mathrm{Pb}$ & 0.34 & 0.27 & 0.068 & 0.54 & 1.2 & 500 \\
\hline $\mathrm{Sb}$ & 2 & 0.11 & 0.4 & 3.6 & 12 & 60 \\
\hline $\mathrm{Se}$ & 10 & 0.38 & 2 & 15 & 27 & 100 \\
\hline $\mathrm{Zn}$ & 3.1 & 0.28 & 0.62 & 4.9 & 11 & 4,000 \\
\hline DOC & 3,000 & 0.17 & 600 & 5,200 & 15,000 & 500,000 \\
\hline Phenol index & 100 & 0.3 & 20 & 150 & 330 & 1,000 \\
\hline
\end{tabular}

The WQC are the lowest groundwater or fresh water values from the Nordic countries [18]

The $\kappa$ values used are those used in the calculation of the EU WAC for landfilling of inert waste [14]

The EU Inert landfill WAC are those listed in EU Council Decision 2003/33/EC [16]

in Table 2 which also indicates which parts of the sourcepathway-receptor chain will be affected (in terms of modelling conditions) by the measures taken. The two most basic requirements that will set the scene for the proposed methodology for development of leaching limit values as part of EoW criteria are: (1) the aggregate can only be used for specified purposes, and (2) the aggregate must be taken back by the user/owner at the end of its service life.

The first of these requirements is already implied in indent (a) in Article 6 (1) of the WFD, but it should be further specified and refer to one or more specific application or scenario type(s), e.g., use as sub-base in a road or as a filling material in an embankment. This requirement could then lead to more than one set of limit values (corresponding to different application purposes) or, if that is considered impractical, to the adoption of the most restrictive of these for all the relevant purposes. The second requirement, which is for example already part of the Dutch Soil Quality Decree (SQD [10]) will, together with the first requirement, ensure that the risk assessment only has to be performed for specific, relevant in-use scenarios (as opposed to the very conservative scenario applied in the case of free or unrestricted use), albeit always assuming that the material is granular. However, this requirement would still need consideration of aggregate alterations (e.g., carbonation) that may enhance (or reduce) the leaching of substances during the service life. The practical implementation of this requirement will probably require some careful consideration of measures to ensure that the responsibility remains with someone if ownership and other conditions change in the course of a long service life.

\section{Methodology for Development of EoW Leaching Limit Values}

The calculations presented above and shown in Table 1 clearly indicate that if the set of criteria to be met by wastederived aggregates in order to obtain EoW status at EU level in accordance with Article 6 (1) of the WFD does not include specific conditions for and restrictions of the use of the aggregates as construction products, it will be necessary to require such stringent environmental protection measures in terms of leaching limit values, that very few, if any, waste-derived aggregates will be able to comply with them.

It is therefore strongly recommended to include conditions on the use of aggregate products as part of the EoW criteria and to develop leaching limit values that reflect 
Table 2 Overview of conditions that may be imposed on the use of waste-derived aggregates as part of EoW criteria

\begin{tabular}{|c|c|c|c|}
\hline Imposed condition & Source & Pathway & Receptor \\
\hline $\begin{array}{l}\text { The material can only } \\
\text { be used for specified } \\
\text { purposes }\end{array}$ & Can be influenced & Can be influenced & $\begin{array}{l}\text { May determine } \\
\text { which receptors } \\
\text { are relevant }\end{array}$ \\
\hline $\begin{array}{l}\text { Take back the material } \\
\text { after service life }\end{array}$ & $\begin{array}{l}\text { Reduction in the } \\
\text { time span to be } \\
\text { considered }\end{array}$ & Not affected & Not affected \\
\hline $\begin{array}{l}\text { Minimum distance to } \\
\text { groundwater level }\end{array}$ & Not affected & $\begin{array}{l}\text { Attenuation in the unsaturated } \\
\text { zone may be taken into account }\end{array}$ & Depends on POC \\
\hline $\begin{array}{l}\text { Minimum distance to } \\
\text { surface water }\end{array}$ & Not affected & $\begin{array}{l}\text { Attenuation in the unsaturated } \\
\text { zone and the aquifer may be } \\
\text { taken into account }\end{array}$ & Depends on POC \\
\hline $\begin{array}{l}\text { Restrictions on height of } \\
\text { application }\end{array}$ & $\begin{array}{l}\text { May reduce source } \\
\text { term }\end{array}$ & Not affected & Not affected \\
\hline $\begin{array}{l}\text { Restrictions on the } \\
\text { length and width of } \\
\text { the application }\end{array}$ & $\begin{array}{l}\text { May reduce the } \\
\text { source term }\end{array}$ & Not affected & Not affected \\
\hline $\begin{array}{l}\text { Restrictions on allowed } \\
\text { rate of infiltration }\end{array}$ & $\begin{array}{l}\text { Reduction of the } \\
\text { flux (the load per } \\
\text { time unit) }\end{array}$ & Not affected & Not affected \\
\hline
\end{tabular}

these conditions. The authors propose a generic stepwise (iterative) modelling approach that can be used to develop leaching limit values as (part of) EoW criteria for wastederived aggregates, taking into account any of the conditions described in Table 2 above. The approach is in agreement with the principles described in EN 12920: "Characterisation of waste-Methodology for the determination of the leaching behaviour of waste under specified conditions" [21] and it is also applicable to the setting of criteria for utilisation of the materials under waste legislation. It is based on the same fundamental principles that have been applied in the setting of the EU leaching criteria for acceptance of waste at inert waste landfills (see e.g., Hjelmar [14] in [18]) and in the development of leaching criteria for application of virgin and waste materials under the Dutch Soil Quality Decree ([10]). The stepwise procedure which is briefly outlined in Table 3 could in fact also be applied to the setting of limit values for the use of waste-derived aggregates without conditions or restrictions and would, in that case, reach results similar to those described in Table 1. Calculations using the stepwise methodology with various conditions imposed on the use have shown that for e.g., use of aggregates as road sub-base or base, the calculated limit values for several substances are of the same order of magnitude as the EU WAC for inert waste landfills [18]. The source and transport modelling and reverse modelling described in steps 3, 4 and 5 in Table 3 are state of the art and have been applied on several occasions, including when the European leaching criteria for acceptance of waste at landfills were developed [14]. The methodology can be applied using generic scenarios, e.g., for the generation of EoW criteria at a national or European scale, or using site-specific information and generating more exact criteria for one specific application and location.

\section{Testing and Documentation Requirements}

It is proposed that documentation in relation the potential achievement of EoW status for a waste-derived aggregate should be provided in the form of a dossier (similar to the one developed for Initial Type Assessment (ITA) under the CPR/CPD, see e.g., [22]). The dossier should include proof that a broad and representative range of the aggregate in question complies with the leaching limit values developed. The dossier should include results of percolation tests (CEN/TS 14405 or CEN/TC 351/TS-3), pH dependence tests (CEN/TS 14429 or CEN/TS 14997) and batch leaching tests EN 12457-part 1, 2 or 3 (for future compliance/factory production control (FPC) or routine purposes). The analytical programme considered should as a minimum for initial type testing (ITT) include all major substances (mainly salts) and all relevant substances for which WQC exist in the EU Member States. Dissolved organic carbon (DOC) should be analysed in the test eluates because of its ability to enhance the leaching of metals and persistent organic pollutants (POPs). ITT should also include determination of the total content of a number of substances. As a minimum requirement for ITT, analysis of content should for example account for at least $95 \%$ of the mass of the material and include total organic carbon (TOC), polychlorinated biphenyls (PCB), benzene, toluene, ethylbenzene and xylenes (BTEX), polycyclic aromatic hydrocarbons (PAH) and hydrocarbons and any inorganic substances of concern (unless they can be definitively excluded on the basis of the origin of the aggregate). The 
Table 3 Outline of the proposed stepwise methodology for development of EoW leaching criteria for aggregates

\begin{tabular}{|c|c|}
\hline Stepwise procedure & Major actions taken at each step \\
\hline $\begin{array}{l}\text { Step 1: Description of the application and the } \\
\text { imposed conditions }\end{array}$ & $\begin{array}{l}\text { The specified application and the conditions imposed are described (see } \\
\text { Table 2). }\end{array}$ \\
\hline $\begin{array}{l}\text { Step 2: Description of the relevant receptor(s) and } \\
\text { the primary water quality criteria }\end{array}$ & $\begin{array}{l}\text { The receptor (groundwater or surface water) is selected and appropriate water } \\
\text { quality criteria are chosen (based on European or lowest national values). }\end{array}$ \\
\hline Step 3: Description and modelling of the source term & $\begin{array}{l}\text { Modelling of the flux of substances as a function of time based on the chosen } \\
\text { application, the imposed conditions, and the assumed climatic conditions. }\end{array}$ \\
\hline $\begin{array}{l}\text { Step 4: Description and modelling of the migration } \\
\text { of substances from the source to the point of } \\
\text { compliance (POC) }\end{array}$ & $\begin{array}{l}\text { Modelling of the transport of substances from the source to the receptor, taking } \\
\text { into account the mitigating effects of the imposed conditions and the } \\
\text { attenuation/dilution effects in soil, groundwater and surface water. }\end{array}$ \\
\hline $\begin{array}{l}\text { Step 5: Assessment of the impact at the receptor and } \\
\text { reverse modelling or iteration to adjust the source } \\
\text { term to the primary WQC }\end{array}$ & $\begin{array}{l}\text { The peak values of the substances at the POC are calculated, and the relationship } \\
\text { between peak value and initial concentration at the source is established by } \\
\text { reverse modelling or iterative modelling. The source term concentration } \\
\text { corresponding to a peak value corresponding to the WQC is established. }\end{array}$ \\
\hline $\begin{array}{l}\text { Step 6: Transformation of source term criteria to } \\
\text { specific limit values }\end{array}$ & $\begin{array}{l}\text { The resulting initial source term concentration }\left(\mathrm{C}_{0}\right) \text { corresponding to the WQC at } \\
\text { the POC can be converted to corresponding limit values at } \mathrm{L} / \mathrm{S}=2 \mathrm{1} / \mathrm{kg} \text { and } \\
10 \mathrm{l} / \mathrm{kg} \text {, assuming an exponential decrease of the concentration with } \mathrm{L} / \mathrm{S} \text {. }\end{array}$ \\
\hline $\begin{array}{l}\text { Step 7: Assessment of the resulting limit values and } \\
\text { possible repetition of the stepwise procedure }\end{array}$ & $\begin{array}{l}\text { For the same receptor and the same WQC, the limit values calculated for use } \\
\text { with conditions imposed are likely to be considerably less stringent than for the } \\
\text { case without conditions. If the leaching limit values calculated for a given set } \\
\text { of conditions are considered too restrictive, the procedure can be repeated with } \\
\text { additional or more effective conditions to find new limit values. }\end{array}$ \\
\hline $\begin{array}{l}\text { Step 8: Taking other considerations into account } \\
\text { e.g., to modify relatively high limit values that } \\
\text { may be calculated based on the impact on } \\
\text { groundwater and surface water alone }\end{array}$ & $\begin{array}{l}\text { Issues that could lead to adjustment of calculated limit values could include } \\
\text { consideration of other legislation, reluctance to create potential landfills, } \\
\text { consideration of adverse effects (e.g., mobilisation) of one substance on } \\
\text { another, consideration of possible corrosion effects and consideration of } \\
\text { particular exposure conditions not accounted for in the water impact } \\
\text { assessment model. }\end{array}$ \\
\hline
\end{tabular}

analytical programmes for subsequent FPC testing of leaching and content be based upon the findings in the ITT and may be substantially reduced as compared to the ITT programme. It is recommended that for a given wastederived aggregate for which EoW criteria may be established at EU level, the appropriate CEN Technical Product Committee should define different classes in the relevant Product Standard according to different levels of restrictions of or conditions on the use and associated different sets of limit values for EoW classification. Member States can then decide which classes they allow to be used on their territory.

\section{Conclusions}

Waste-derived aggregates are being considered as possible candidates for development of EoW criteria at EU level in accordance with Article 6 (1) of the EU WFD as a means of increasing the recovery of resources. Only the UK has started establishing national EoW criteria for some wastederived aggregates. If and when a waste-derived aggregate achieves EoW status, it will become a (construction) product and hence regulated by the CPR rather than waste legislation which means that in most EU Member States there will be no applicable environmental protection regulation. Recycled waste aggregates are subject to environmental legislation in several EU Member States, but construction products are generally not, except in The Netherlands where environmental protection regulations apply equally to both recycled waste aggregates and virgin aggregates used in construction. Due to the potential lack of existing environmental protection regulation applying to waste-derived aggregates with EoW status that are used for construction purposes, it is important that the criteria an aggregate must fulfil to achieve and maintain EoW status ensure sufficient protection of the environment and human health. The example calculation shown in this paper clearly indicates that if the EoW criteria do not include specified conditions for the use of waste-derived aggregates with EoW status for specific purposes, then leaching limit values aimed at the protection of soil, groundwater and surface water will have to so stringent that very few, if any, waste aggregates can meet them. Instead it is proposed to impose restrictions and conditions on the use as part of possible future EoW criteria for waste-derived aggregates, and a step-wise methodology for development of more realistic leaching limit values for EoW is outlined. The methodology incorporates the mitigating effects of various measures that reduce the potential environmental impact of 
construction applications with waste-derived aggregates. Calculations using this methodology and imposing various conditions on the use of waste-derived aggregates e.g., as road-base have been reported to result in limit values that for several substances are of the same order of magnitude as the EU WAC for inert waste landfills. Recommendations are also made of the practical testing and documentation procedures for aggregates with EoW status within the framework of the CPR.

Acknowledgments Parts of the work discussed in this paper was financed by the Nordic Council of Ministers [18].

Open Access This article is distributed under the terms of the Creative Commons Attribution License which permits any use, distribution, and reproduction in any medium, provided the original author(s) and the source are credited.

\section{References}

1. Directive 2008/98/EC of the European Parliament and of the Council of 19 November 2008 on waste and repealing certain Directives. OJ L 312, 22.11.2008

2. Delgado, L., Catarino A.S., Eder, P., Litten, D., Luo, Z., Villanueva, A.: End of Waste Criteria, final report. JRC Scientific and Technical Reports. European Commission, Joint Research Centre, Institute for Prospective Technological Studies, Seville, Spain, (2009)

3. IPTS: Study on the selection of waste streams for End of Waste assessment. Final Report. JRC Scientific and Technical Reports. European Commission, Joint Research Centre, Institute for Prospective Technological Studies, Seville, Spain, (2009)

4. Council Regulation (EU) No 333/2011 of 31 March 2011 establishing criteria determining when certain types of scrap metal cease to be waste under Directive 2008/98/EC of the European Parliament and the Council. OJ L 94, 8.4.2011

5. Environment Agency: www.environment-agency.gov.uk/business/ sectors/124299.aspx (2012). Accessed 15 Oct 2012

6. Regulation (EU) No 305/2011 of the European Parliament and of the Council of 9 March 2011 laying down harmonised conditions for the marketing of construction products and pealing Council Directive 89/106/EEC. OJ L 88, 4.4.2011

7. Council Directive 89/106/EEC of 21 December 1988 on the approximation of laws, regulations and administrative provisions of the Member States relating to construction products. OJ L 40, 11.2.1889

8. Regulation (EC) No 1907/2006 of the European Parliament and of the Council of 18 December 2006 concerning the Registration, Evaluation, Authorisation and Restriction of Chemicals (REACH), establishing a European Chemicals Agency, amending Directive 1999/45/EC and repealing Council Regulation (EEC) No 793/93 and 91/155/EEC, 93/67/EEC, 93/105/EC and 2000/21/ EC. OJ L 396, 30.12.2006-and subsequent amendments
9. Guidance on waste and recovered substances. European Chemicals Agency (ECHA), Version: 2, Helsinki, Finland, (May 2010). Available at http://echa.europa.eu

10. Soil Quality Decree. Staatscourant 20 Dec 2007, Nr. 247, 67-90, The Netherlands

11. Böhmer, S., Moser, G., Neubauer, C., Peltoniemi, M., Schachermayer, E., Tesar, M., Walter, B., Winter, B.: Aggregates case study, Final Report referring to contract $n^{\circ}$ 150787-2007 F1SCAT "Aggregates case study-data gathering" (study commissioned by JRC-IPTS), Vienna, (2008)

12. Regulation (EC) No 1013/2006 of the European Parliament and of the Council of 14 June 2006 on shipments of waste. OJ L 190, 12.07.2006 - and subsequent amendments

13. WRAP, Environment Agency (England) and Northern Ireland Environment Agency: Quality Protocol, Pulverised Fuel Ash (PFA). End of waste criteria for the production of pulverised fuel ash and furnace bottom ash for use in bound and grout applications in specified construction and manufacturing uses (October 2010). Available at www.wrap.org.uk

14. Hjelmar, O.: Description of the methodology used to set the leaching criteria for acceptance of waste at landfills for intert waste, landfills for non-hazardous waste accepting stable, nonreactive hazardous waste and landfills for hazardous waste listed in Council Decision 2003/33/EC, (February 2012). Appendix 8 in [18]

15. Återvinning av avfall I anläggningsarbeten. Handbok. 2010:1. Naturvårdsverket, Stockholm, Sweden (2010)

16. Council Decision 2003/33/EC of 19 December 2002 establishing criteria and procedures for the acceptance of waste at landfills pursuant to Article 16 of and Annex II to Directive 1999/31/EC. OJ L 11, 16.1.2003

17. Directive 2000/60/EC of the European Parliament and of the Council of 23 Oct 2000 establishing a framework for Community action in the field of water policy. OJ L 327, 22.12.2000

18. Hjelmar, O., Hansen, J.B., Wahlström, M., Wik, O.: End-ofWaste Criteria for Construction and Demolition Waste. Report for Nordic Council of Ministers, DHI, Hørsholm, Denmark, (2013). Available upon request from oh@dhigroup.com

19. Van der Sloot, H.A., Seignette, P., Comans, R.N.J., van Zomeren, A., Dijkstra, J.J., Meeussen, H., Kosson, D.S., Hjelmar, O.: Environmental performance of waste materials. In: Dhir, R.K, Newlands, M.D., Halliday, J.E. (eds.): Recycling and Reuse of Waste Materials. Proceedings of the International Symposium held at University of Dundee, Scotland, UK on 9-11 September 2003, Thomas Thelford, London, pp. 769-789 (2003)

20. Aalbers, Th.G., de Wilde, P.G.M., Rood, G.A., Vermij, P.H.M., Saft, R.J., van de Beek, A.I.M., Broekman, M.H., Masereeuw, P., Kamphuis, Ch., Dekker, P.M., Valentijn, E.A.: Environmental quality of primary and secondary construction materials in relation to re-use and protection of soil and surface water. RIVMreport no.: 771402007. National Institute of Public Health and the Environment, Bilthoven, The Netherlands (1996)

21. EN 12920 + A1:2008: Characterisation of waste-Methodology for the determination of the leaching behaviour of waste under specified conditions

22. CEN/TR 15858: Construction products-Assessment of the release of regulated dangerous substances from construction products based on the WT, WFT/FT procedures, (2009) 